\title{
The importance of the transport system in shaping the growth and form of kimberlite volcanoes
}

\author{
Murray McClintock ${ }^{\mathrm{a}}$, Pierre-Simon Ross ${ }^{\mathrm{b},{ }^{*}}$ James D.L. White $^{\mathrm{c}}$ \\ a Volcanic Solutions Ltd, 20 Moray Place, Dunedin 9013, New Zealand (murray@ volcanicsolutions.com); \\ ${ }^{\mathrm{b}}$ Institut national de la recherche scientifique, centre Eau-Terre-Environnement, 490 rue de la Couronne, Québec (QC), \\ G1K 9A9, Canada, Phone +1-418-654-3773, fax +1-418-654-2600, email rossps@ete.inrs.ca \\ ${ }^{\mathrm{c}}$ Department of Geology, University of Otago, P.O. Box 56, Dunedin, New Zealand \\ (james.white@stonebow.otago.ac.nz) \\ * Corresponding author
}

\begin{abstract}
Understanding the range of transport styles recorded by kimberlite deposits is key to describing the type and style of eruptions. Building a clear picture of the processes that shape deposits is essential for selecting exploration targets and evaluating the grade and value of diamond-bearing kimberlites. Variations in grade reflect differences in the diamond content of different magma parcels erupted during the lifetime of the kimberlite volcano, sorting during transport of eruption products, or re-working of diamonds during crater growth, cone collapse and erosion.

The form of the kimberlite volcano is largely determined when the magma arrives near the surface. If magma comes into contact with external water, transport will be driven by a combination of magmatic gases + steam. From a diamond exploration perspective, the resulting deep diatremes make the most attractive targets because they survive erosion and form large geophysical anomalies. If water is too abundant, a tuff cone or tuff ring with no diatreme or a shallow one will form. On the other hand, if external water is very limited or if the conduit is rapidly sealed by chilled melt, the transport system will be driven by magmatic gases alone. The result will then be a spatter cone or cinder cone underlain by a dike, possibly with a related lava flow, but with no diatreme.
\end{abstract}

Keywords

Kimberlites, diatremes, diamonds, transport processes, sorting, phreatomagmatism

\section{Introduction}

Transport of kimberlite magma from the mantle to or near the surface is a complex process that involves many, often sudden and dramatic, changes in transport style. The pace and magnitude of changes in the transport system accelerate as the magma nears the surface, culminating in eruptions during which multiple transport events take place simultaneously as well as single transport events that change significantly from their point of origin to final deposition. Variations in diamond grade reflect differences in the diamond content of different magma batches erupted during the lifetime of the volcano, sorting during transport of eruption products, or re-working of diamonds during crater growth, cone collapse and erosion. This paper sets out the source and signature of transport events during the evolution of kimberlite volcanoes with an emphasis on observations that can be distilled from field data, drill cores and thin sections. The discussion is weighted toward transport systems in diatremes and craters because the full spectrum of kimberlite volcanism is not covered by existing field data, although some useful interpretations can be drawn from the few described examples of surface kimberlite deposits as well as by comparison with equivalent small-volume volcanic systems.

\section{Deep transport systems control delivery of magma and diamonds to eruption sites}

The initial stages of kimberlite transport involve rise of magma in narrow dikes (e.g., Dawson and Hawthorne, 1970). There is compelling evidence that kimberlite magmas are extracted from their source region and erupted without significant residence times in the crust (e.g., Mitchell, 2008). In this respect, kimberlites have much in common with monogenetic continental volcanoes, each inferred to record shortlived eruption of a single magma batch. On the other hand, careful examination of the volcanic products of monogenetic eruptions, combined with geochemical work on single eruption phases, reveals that many socalled monogenetic volcanoes are in fact composite landforms that record episodic activity at the same site over significant time periods. There is a growing body of evidence that this variation often records ascent of new, unique magma batches from the mantle (Nemeth et al., 2003; McClintock et al., 2008a). 
Likewise, many single kimberlite volcanoes have significant variations in diamond grade between different kimberlite phases, suggesting eruption of distinct (perhaps unrelated) magma parcels at the same site. In some kimberlites, different magma batches were erupted at the same site during short-lived pulses of activity separated by long periods of volcanic quiescence. For example, single kimberlite complexes in the Fort à la Corne field in Canada have been constructed by at least seven brief episodes of activity over a period of 5 to 7 million years (Kjarsgaard et al., 2006, 2008). Persistent re-occupation of the deep magma transport system by kimberlite melts suggests that stable, deeply tapping magma pathways are the key feature of the deep kimberlite transport system.

\section{Shallow transport systems shape volcanoes}

The deposits described to date indicates that emplacement of kimberlite involves processes that range from intrusion of shallow sills, sheets and dikes to violent eruptions that quarry deep diatremes into hard rocks. Tuff cones and rings constructed by eruptions of kimberlite magma have been described from Fort à la Corne (e.g., Leckie et al., 1997; Zonneveld et al., 2004; Lefebvre and Kurszlaukis, 2008). Kimberlite scoria cones and lava flows are rare but the examples described to date are made up of deposits much like scoria and lava formed by other mafic to ultramafic magma types (e.g., Reid et al., 1975; Dawson, 1994). It is unlikely that the range of kimberlite volcanoes preserved in the rock record, made up of many diatremes and intrusions and very few volcanic cones and lavas, is representative of the range that forms in nature.

\subsection{Transport within diatremes}

Because of their characteristic geophysical signature relative to host rocks and excellent preservation potential in eroded terrains, and thus preserved volume, diatremes represent the favoured target for diamond explorers. Understanding the processes that shape kimberlitic diatremes is essential to accurately evaluate the grade of diamond deposits and to target high-grade parts of large or marginally economic kimberlite bodies. Diatremes form during eruption of the full spectrum of magma compositions and have been well studied (e.g., Hearn, 1968; Lorenz, 1975, 1979, 1986, 2003; White, 1991).

In the absence of significant erosion, diatremes are overlain by maar craters (Figs. 1a, 1b). The maars are surrounded by tephra rims, which are typically rich in country rock fragments when erupted through hard rocks (Fig. 1c). Diatremes can range from small pipe-like bodies tens of metres deep that may merge at depth with irregular "budded" dikes to deep funnel-shaped structures that extend for hundreds to thousands of metres below the surface (Hawthorne, 1975; Mitchell, 1986; Clement and Reid, 1989). Although some diatremes have uniform cross-sections and form regular inverted cone-shaped bodies, many diatremes have very irregular shapes that reflect local structural controls or coalescence of two or more adjacent structures. Extreme examples of diatreme coalescence has produced laterally extensive "nested" diatreme complexes that are tens of square kilometres in area (e.g., Coombs Hills, Antarctica: White and McClintock, 2001; McClintock and White, 2006; Ross and White, 2006).

Diatremes are problematic to interpret because (i) the eruptions are not observable in the below-ground part of the system; and (ii) the deposits that fill diatremes are often structureless - especially in their lower parts - and thus contain few sedimentological clues to guide reconstruction of their formation. Unravelling the characteristics of the transport system is complex because they simultaneously act as sites of deposition and eruption. It follows that deposits in diatremes record a much better picture of the final stages of diatreme development than they do of the early stages. Some key features are:

1. Non-bedded or very weakly bedded, poorly sorted volcaniclastic deposits, often with a "well-mixed" aspect (incorporating country rock fragments from many stratigraphic levels) that occupy the central and lower parts of the structure (e.g., Tait et al., 2006; Fig. 1d). The upper part of the diatreme can be bedded (e.g., Hearn, 1968).

2. Some diatremes include metre- to tens of metrescale megablocks of wall-rock that have subsided hundreds of metres below their original stratigraphic position (e.g., Clement and Reid, 1989). Megablocks of syn-eruptive volcaniclastic deposits originally deposited on the ground surface (pieces of the tephra rim) are sometimes found as well in large diatremes (Fig. 1e). In one example, a quarter of a tephra rim is now enclosed in ventfilling rocks, implying that the small edifice (original radius $\sim 200 \mathrm{~m}$ ) was "eaten" from below by a laterally propagating diatreme, and partly subsided into it (Ross et al., 2008a; Fig. 1f).

3. Irregular igneous intrusions tangled with diatremefilling rocks, mostly preserved in the lower diatreme and the root zone (White and McClintock, 2001; Fig. 1d). Many dikes and sheets show features consistent with transport of magma into and through diatreme fill soon after it formed (peperite, for example, which implies a wet vent fill) and some dikes extend right through diatreme fill to feed lava flows and form scoria cones at the surface (Fig. 2a).

4. Contacts with wall-rocks vary from sharp to gradational (brecciated) within single diatremes and from one diatreme to adjacent ones. The angle of these contacts is often steep $\left(>60^{\circ}\right)$ but varies from shallow dips to vertical contacts. Variation in the dip and nature of wall-rock contacts is strongly influenced by the strength of country rocks (Lorenz, 2003; Sohn and Park, 2005) and local structural controls.

5. Clasts that record multiple cycles of fragmentation and transport are common (Figs. 2b, 2c, 2d).

6. Juvenile clasts are of wide-ranging but mostly low vesicularity, as is the case in tephra rims around maars (Fisher and Schmincke, 1984). This is generally true of all diatremes of any magma composition (e.g., Fig. 3). Many diatreme fills include a subset of moderately to highly vesicular clasts, but the majority of juvenile clasts are 
vesicle-poor ( $<30 \%$ vesicles). We emphasize that non-vesicular to vesicle-poor juvenile fragments are not restricted to kimberlitic diatremes.

7. Welded deposits are rare in diatremes, although welding is common in some surface deposits that overly them (e.g., scoria/spatter cones). Measured and inferred emplacement temperatures in diatremes are significantly cooler than the temperature of erupting magma (e.g., Mitchell, 1986; Stasiuk et al., 1999).

The wide range of vesicularity $(\leq 5 \%$ to locally $\geq 75 \%$ ) in juvenile clasts within single packages of polymict volcaniclastic rock in diatremes indicates that magma was fragmented at different points in its degassing history (Houghton and Wilson, 1989). Rapid lateral changes in the componentry and grain size of deposits suggests that discrete, repeated transport events involving relatively small volumes of debris were more important than sustained ones.

Steep internal contacts within diatremes indicate that transport is dominated by sub-vertical movement of vent-filling debris. The fill of some large diatremes can be subdivided into a number of discrete phases distinguished by variation in componentry or diamond grade (in kimberlites) that are bounded by steep contacts (e.g., White, 1991; Ross and White, 2006; Brown et al., 2008a; van Straaten et al., 2008). These different rock units were emplaced adjacent to each other in stages rather than during a major, more or less continuous pipefilling event (cf. Sparks et al., 2006; Cas et al., 2008). Studies of diamond mines demonstrate that these distinct phases describe sub-vertical domains that can be traced for tens to hundreds of metres downward (e.g., Clement and Reid, 1989; Kjarsgaard, 2007; Kurszlaukis et al., 2008; Tait and Brown, 2008). In map view, these crosscutting domains have cylindrical to irregular outlines and sharp to diffuse contacts (Figs. 2e, 2f).

In combination, the characteristics of the polymict, poorly sorted, non-bedded deposits in diatremes are inferred to be most consistent with transport by downward mass movement and upward moving debris jets (McClintock and White, 2006; Ross and White, 2006; Kurszlaukis et al., 2008; Ross et al., 2008b, 2008c). Because eruption bursts are episodic and mostly happen toward the base of the diatreme, transport of debris follows a cycle from upward-dominated transport to downward-dominated transport. Localised transport styles such as wall-rock collapse sideways and downward into the vent, slumping and surface fallback play key roles in the transport system as and immediately after ejecta moves through it (White, 1996). The massive, poorly sorted, "well-mixed" deposits so characteristic of diatremes are the consequence, at least in part, of repeated disruption and recycling of earlyformed deposits and destruction of sedimentary structures (White, 1991, 1996; Kurszlaukis and Lorenz, 2008). Slumping and sliding of debris after initial deposition further obscures original deposit structure to yield the non-bedded units that comprise the bulk of the diatreme fill (Houghton and Nairn, 1991).

Fluidisation by gas flow (e.g., Woolsey et al., 1975; Walters et al., 2006; Gernon et al., 2008a) and liquefaction by shaking or shearing may be locally important transport styles, as shown by the presence of elutriation pipes in some African kimberlites (Gernon at al., 2008b). But the influence of these processes is restricted to modification of existing deposits rather than efficient, substantial transport of large volumes of debris through and beyond deep diatremes. Not enough gas can possibly be extracted from metre-scale kimberlite dikes - like those feeding magma into diatremes - to completely fluidise a large, cone-shaped pipe (Lorenz and Kurszlaukis, 2007).

Non-kimberlitic maar-diatreme volcanoes grow over days, weeks, or perhaps months or years for the larger ones, through discontinuous, small explosive bursts. We expect the same slow growth story to hold true for kimberlitic diatremes; Kurszlaukis and Lorenz (2008) referred to this as the "machine-gun model", by opposition to "big bang models". As the kimberlite volcano grows, the diatreme and crater will become larger than any single vent site within it. Very early in the volcano development, single shallow eruption bursts can eject all the debris from the diatreme and effectively empty it. On the other hand, when the crater is larger than the active vent, single eruption bursts might be able to punch through existing deposits and disrupt them but the diatreme remains mostly full of debris from one eruption burst to the next. Some eruption bursts may never escape the confines of the vent with the result that particle transport remains entirely subterranean (McClintock and White, 2006; Ross et al., 2008b, $2008 \mathrm{c}$ ). At this point, the diatreme becomes the key depocenter for fragmented magma and diamonds, progressively capturing more and more ejecta as it grows.

\subsection{Intra-vent and vent-proximal transport of hot, sticky particles}

One clast type characteristic of kimberlite deposits are round or sub-round ash- to lapilli-sized "pelletal" clasts (e.g., Mitchell, 1997; Hetman et al., 2004). These non-vesicular or poorly vesicular juvenile fragments are often cored by large crystal grains. Tangential alignment of small minerals sub-parallel to clast margins is common. Analogous sub-round to round clasts of congealed magma are described from scoria cones of olivine- or melilite-nephelinite composition (Bednarz and Schmincke, 1990; Lorenz and Zimanowski, 2000), carbonatitic diatremes (Kurszlaukis and Lorenz, 1997), kamafugitic diatremes (Junqueira-Brod et al., 2005) and basalt to basaltic-andesite cones and craters (Heiken and Wohletz, 1985; McClintock et al., 2008b). At each of these sites, formation of dense, sub-round fragments of magma is ascribed to low magma viscosity combined with relatively high ejection speeds. Clasts are shaped by surface tension effects during transport, shortly after fragmentation of magma.

Some models that invoke particle acceleration driven by magmatic degassing suggest that the absence of vesicles in kimberlitic clasts can be explained by gas escape during transport (e.g., Cas et al., 2008), but surface tension forces strong enough to shape melt droplets will also act to trap gas bubbles. The paucity of vesicles in pelletal lapilli suggests that gas loss occurred before the magma was disrupted into droplets, or that 
vesicles never formed in the first place. These deposits argue for transport of liquid to plastic particles as a spray of magma clots in eruption columns high enough to allow clasts to mostly cool before falling back around the vent. Particle concentration must remain low enough to prevent coalescence of magma fragments during transport (Freundt, 1998).

On the other hand, if hot, sticky clasts experience only limited cooling during transport, they will coalesce and weld in the eruption column and on deposition. An absence of vesicles combined with thorough welding indicates magmatic out-gassing and deposition of hot, fluid clasts. Transport in an eruption column containing dense clasts is almost always very limited, although deposits can often flow hundreds of metres or kilometres from their source as clastogenic (rootless or spatter-fed) flows (Sumner, 1998). Absence of significant water in the transport system is implied by the absence of cooling. These deposits commonly form in proximal areas during vigorous fire-fountaining activity (e.g., Head and Wilson, 1989; Sumner et al., 2005). Although welded volcaniclastic rocks are common in volcanic successions worldwide, welded deposits have only been described for kimberlite deposits comparatively recently (e.g., Brown et al., 2008b; van Straaten et al., 2008).

\section{Reworking}

Secondary transport (reworking) of kimberlite takes place at the surface during and after eruptions. The degree of reworking will depend on the type of deposits exposed at the surface, the energy of the sedimentary environment and the length of time deposits are exposed to erosion. Craters trap a significant proportion of reworked debris and accompanying diamonds because they are often the most significant local depocentre. On the other hand, cones quickly degrade unless rapidly buried, and diamonds are redistributed to form local or far-field placer deposits. Diatremes are relatively immune to surface erosion and reworking unless regional tectonics causes much later large-scale uplift. Transport during reworking is dominated by gravity on crater and cone slopes and by water and wind on crater floors and farther afield. Distinguishing reworked from primary deposits can be problematic but, with the exception of mass movement during slumping and sliding, generally contributes to up-grading of deposits by winnowing out wall-rock clasts and concentrating the relatively denser diamonds. Judging by alteration of kimberlite in diatremes, most kimberlite is expected to be rapidly weathered under surface conditions, leaving diamonds and other heavy minerals as the only trace of kimberlite volcanism in the rock record.

\section{Driving forces of kimberlite transport systems}

Since the 1970s, a divide has developed between the favoured model for formation of the most common type of kimberlite volcano, represented by kimberlitic diatremes, and of diatremes formed by eruption of all other magma compositions.

\subsection{Phreatomagmatic explosions}

Phreatomagmatic eruptions produce short-lived, powerful explosions that fragment magma and wall- rocks and rapidly accelerate a mixture of debris and fluids out of the vent. Phreatomagmatism involving a "normal" (i.e. not excessive) amount of groundwater forms craters excavated below the original ground surface (maars), surrounded by thin tephra rims. Interaction of magma with abundant surface water or very shallow, water-rich aquifers forms tephra rims without deep craters (also known as tuff rings when the tephra is consolidated; Fisher and Schmincke, 1984). In emergent settings, tuff cones are formed (e.g., the Surtsey 1963-64 eruption off Iceland; White and Houghton, 2000).

In shallow vents, the erupted mixture rapidly expands to form dense to dilute pyroclastic density currents and convecting plumes. If eruptions are relatively weak, fall deposition is more dominant than flow deposition, building steep cones of debris around vents. Oversteepening leads to frequent cone collapse, redistributing ejecta and reshaping the inner and outer cone flanks. Transport of debris - including diamonds, if applicable - away from vents is limited, and deposits are mostly poorly sorted. More powerful eruptions are dominated by density currents (flows and surges) and pyroclastic fall that spread debris over a wider area, forming low-profile rings around vents that transition outward into sheet-like deposits. Debris can be carried hundreds of metres or kilometres from vent sites.

\subsection{Magmatic explosive eruptions}

Magmatic eruptions are often more continuous and transport systems are more stable, dominated by pyroclastic fall and flow. Variation in the balance between magma rise speed and bubble rise speed determines whether transport processes are continuous or episodic (e.g., Parfitt, 2004). Continuous eruption styles result in stable transport systems that build cones close to the vent (scoria cones, spatter cones, etc.) and blanket more distal areas with moderately to well-sorted debris. Episodic magmatic eruptions are driven by the bursting of large bubbles and thus are weak, resulting in limited transport of mostly coarse debris that piles up adjacent to vents (strombolian-style activity).

Importantly, wall-rock typically makes up only a limited proportion $(<10 \%$, often $<<1 \%)$ of magmatic deposits (e.g., Valentine et al., 1996); because most fragmentation takes place by bubble-bursting in the upper part of the conduit as magma rises and decompresses, energy and transport is directed upward rather than outward into wall-rocks. From an economic standpoint, magmatic deposits will have lower dilution effects from wall-rock than phreatomagmatic deposits. An exception are deposits formed during intense but short-lived vent-forming (or widening) eruption phases.

High eruption rates accompanied by limited transport can lead to formation of spatter-fed (clastogenic) flows that form where hot ejecta piles up close to vents and fragments weld together. Although initial particle transport is very limited, still-hot welded deposits may be carried hundreds of metres from vents by secondary transport in spatter-fed lava flows (Sumner, 1998). Lava flows also form as gas contents of magma begin to fall (Parfitt, 2004). Both spatter-fed flows and other lavas produce almost zero sorting of material in the magma 
such as megacrysts, and will therefore have diamond content and distribution that is close to that of the erupting kimberlite magma.

\subsection{The case for phreatomagmatism in kimberlitic diatremes}

Kimberlitic and non-kimberlitic diatremes are dominated by deposits that point to energetic but episodic eruptions, multiple cycles of transport, incremental crater growth and deposition of small parcels of debris. Although a number of current models argue that the dominant, or the only, driver of kimberlite eruptions is violent exsolution of magmatic volatiles (e.g., Sparks et al., 2006; Wilson and Head, 2007; Cas et al., 2008; Porritt et al., 2008; Scott Smith, 2008), there is no physical evidence whatsoever for magmatic volatiles playing a dominant role in the eruptions that form diatremes.

Kimberlite clasts in diatremes are typically vesiclefree or vesicle-poor, just like in non-kimberlitic diatremes. This "anomaly" - from the point of view of the magmatic model - is inferred to reflect some unusual quality of kimberlite melts that allow them to be accelerated by gases that then efficiently escape the melt before quenching (e.g., Cas et al., 2008). The validity of this hypothesis cannot be adequately tested at the present time. On the other hand, arrested vesiculation and abundant country rock fragments are hallmarks of phreatomagmatic eruptions (Houghton and Wilson, 1989; Thordarson et al., 2003). In addition to this physical evidence, perhaps the most compelling argument for formation of kimberlitic diatremes by phreatomagmatic processes is the formation of extremely similar volcanic landforms, deposits and structures by magma types of known volatile content and for which field studies and observations of actual eruptions have established beyond doubt derive from explosive magma-water interaction.

In this case, are all kimberlites phreatomagmatic? The case for phreatomagmatic eruption of kimberlite magma is often challenged by the assertion that it seems inherently unlikely that all kimberlite magmas are able to seek out and interact with external water during the final stages of their ascent. This idea pre-supposes that deep diatremes are the only kimberlite volcanoes. In fact, an expanding body of work describes a morecomplete spectrum of kimberlite volcanoes and eruptive styles that includes tuff cones and rings, scoria cones and lava, spatter-fed, clastogenic deposits and a wide range of intrusions. If kimberlite magma rises to the surface without coming into contact with water, scoria cones and lava flows will result. If water is hosted by sub-surface aquifers, diatremes form, and if magma comes into contact with surface water tuff rings and cones develop. In eroded terrains, only the sub-surface expression of the volcanic edifice survives in the rock record. In phreatomagmatic systems, this is represented by dikes and deep diatremes whereas in magmatic systems dikes provide the only record of volcanism at that site.

\section{Transport shapes diamond distribution}

Diamonds are rapidly transported to the surface by kimberlite (or lamproite) magmas that are channelled by deep, stable magma pathways. The transport system changes dramatically when magmas arrive at the surface, and the mode of diamond transport with it. During eruptions, the diamond transport system abruptly changes from one in which diamonds are suspended in magma (or locked in mantle xenoliths) to one in which diamonds are part of a mixture of fragmented magma and wall-rock, and low-density fluids. Depending on the style of eruption, eruption intensity and the processes involved in moving debris from fragmentation sites to depositional sites, diamonds may retain their original concentration relative to the kimberlite magma, or become enriched or depleted by size or density sorting.

Sorting is reduced in diatremes, welded spatter deposits and lava. Sorting is enhanced by expansion of the transport system above the surface in fall and flow deposits. Deposits that have experienced limited sorting such as well-mixed deposits in diatremes or weakly fragmented spatter likely have fairly homogeneous diamond grades, whereas better-sorted fall or density current deposits probably have highly variable diamond grades. Sorting during extra-vent transport is especially effective with water, compared to in air. Contrasts in sorting, and thus diamond grade, can be dramatic. One example is a situation where well-sorted fall deposits alternate with non-sorted spatter-fed flows. These contrasts may also occur in deposits of a single transport event, such as where a tephra jet cascades down the flanks of an emergent cone into standing water and transforms into a strongly sorting subaqueous density current.

One significant unknown is the role of fragmentation and transport during eruptions on breaking large diamonds into smaller pieces. Some of the largest diamonds found are apparently fragments of even larger stones (the Cullinan diamond, for example). Many kimberlite eruptions are powerful enough to fragment hard wall-rocks; the same eruptions very likely fragment diamonds, either during initial fragmentation events or as debris is recycled at the base of the diatreme. In the light of the exponential increase in diamond value with size, a comprehensive dataset is urgently required to address this question. A preliminary prediction is that for any given original diamond size range, the deposits of weak eruptions will have suffered less reduction in diamond grain size by breakage than the deposits of powerful eruptions.

\section{Acknowledgements}

This paper is an extension of the talk given at the Ninth International Kimberlite Conference in Frankfurt am Main, Germany. Our work on diatremes and volcanic systems has been supported by Antarctica New Zealand, Fonds québécois de la recherche sur la nature et les technologies (FQRNT, Canada), the Foundation for Research, Science and Technology (FRST, New Zealand), the Public Good Science Fund (PGSF, New Zealand), the U.S. National Science Foundation (NSF), the University of Otago (New Zealand), and Volcanic Solutions Ltd. We are grateful to many colleagues for 
their advice and information about kimberlites and diatremes.

\section{References}

Bednarz, U. and Schmincke, H.-U., 1990. Evolution of the Quaternary melilite-nephelinite Herchenberg volcano (East Eifel). Bulletin of Volcanology, 52: 426-444.

Brown, R.J., Tait, M., Field, M. and Sparks, R.S.J., 2008a. Geology of a complex kimberlite pipe (K2 pipe, Venetia Mine, South Africa): insights into conduit processes during explosive ultrabasic eruptions. Bulletin of Volcanology. DOI: 10.1007/s00445-008-0211-4

Brown, R.J., Buse, B., Sparks, R.S.J. and Field, M., 2008b. On the welding of pyroclasts from very low-viscosity magmas: examples from kimberlite volcanoes. The Journal of Geology, 116: 354-374.

Cas, R.A.F., Hayman, P., Pittari, A. and Porritt, L., 2008. Some major problems with existing models and terminology associated with kimberlite pipes from a volcanological perspective, and some suggestions. Journal of Volcanology and Geothermal Research, 174: 209-225.

Clement, C.R. and Reid, A.M., 1989. The origin of kimberlite pipes: An interpretation based on a synthesis of geological features displayed by southern African occurrences. In: J. Ross, A.L. Jaques, J. Ferguson, D.H. Green, S.Y. O'Reilly, R.V. Danchin, and A.J.A. Janse (Eds), Kimberlites and related rocks. Geological Society of Australia, Special Publication 14, pp. 632-646.

Crowe, B.M. and Fisher, R.V., 1973. Sedimentary structures in base-surge deposits with special reference to crossbedding, Ubehebe Craters, Death Valley, California. Geological Society of America Bulletin, 84: 663-682.

Dawson, J.B., 1994. Quaternary kimberlitic volcanism on the Tanzania Craton Contributions to Mineralogy and Petrology, 116: 473-485.

Dawson, J.B. and Hawthorne, J.B., 1970. Intrusion features of some hypabyssal south African kimberlites Bulletin Volcanologique, 34: 740-757.

Fisher, R.V. and Schmincke, H.-U., 1984. Pyroclastic Rocks. Springer-Verlag, Berlin, $472 \mathrm{pp}$.

Freundt, A., 1998. The formation of high-grade ignimbrites, I: experiments on high- and low-concentration transport systems containing sticky particles. Bulletin of Volcanology, 59: 414-435.

Gernon, T.M., Gilbertson, M.A., Sparks, R.S.J. and Field, M., 2008a. Gas-fluidisation in an experimental tapered bed: insights into processes in diverging volcanic conduits. Journal of Volcanology and Geothermal Research, 174: 49-56.

Gernon, T.M., Sparks, R.S.J. and Field, M., 2008b. Degassing structures in volcaniclastic kimberlite: examples from southern African kimberlite pipes. Journal of Volcanology and Geothermal Research, 174: 186-194.

Hawthorne, J.B., 1975. Model of a kimberlite pipe. In: L.H. Ahrens, J.B. Dawson, A.R. Duncan and A.J. Erlank (Eds), Physics and Chemistry of the Earth 9. Pergamon Press, pp. 1-15.

Head, J.W. and Wilson, L., 1989. Basaltic pyroclastic eruptions: influence of gas-release patterns and volume fluxes on fountain structure, and the formation of cinder cones, spatter cones, rootless flows, lava ponds and lava flows. Journal of Volcanology and Geothermal Research, 37: 261-271.

Hearn, B.C., 1968. Diatremes with kimberlitic affinities in north-central Montana. Science, 159: 622-625.

Heiken, G. and Wohletz, K., 1985. Volcanic ash. University of California Press, Berkeley, California, 246 pp.

Hetman, C.M., Scott Smith, B.H., Paul, J.L. and Winter, F., 2004. Geology of the Gahcho Kué kimberlite pipes,
NWT, Canada: root to diatreme magmatic transition zones. Lithos, 76: 51-74.

Houghton, B. and Wilson, C.J.N., 1989. A vesicularity index for pyroclastic deposits. Bulletin of Volcanology, 51: 451-462.

Houghton, B.F. and Nairn, I.A., 1991. The 1976-1982 Strombolian and phreatomagmatic eruptions of White Island, New Zealand: eruptive and depositional mechanisms at a 'wet' volcano. Bulletin of Volcanology, 54: 25-49.

Junqueira-Brod, T.C., Gaspar, J.C., Brod, J.A., and Kafino, C.V., 2005. Kamafugitic diatremes: their textures and field relationships with examples from the Goia's alkaline province, Brazil. Journal of South American Earth Sciences, 18: 337-353.

Kjarsgaard, B.A., 2007. Kimberlite diamond deposits. In: W.D. Goodfellow (Editor), Mineral deposits of Canada: a synthesis of major deposits types, district metallogeny, the evolution of geological provinces, and exploration methods. Geological Association of Canada, Mineral Deposits Division, pp. 245-272.

Kjarsgaard, B.A., Harvey, S.E., Zonneveld, J.P., Heaman, L.M., White, D., MacNeil, D., 2006. Volcanic stratigraphy, eruptive sequences and emplacement of the 140/141 kimberlite, Fort à la Corne Field, Saskatchewan. 2006 Kimberlite Emplacement Workshop, Saskatoon, Canada [long abstract], $5 \mathrm{pp}$.

Kjarsgaard, B.A., Harvey, S. and McClintock, M., 2008. Comparative volcanology and emplacement styles of the Star and Orion South kimberlites, Fort à la Corne, Canada. Extended abstract, Ninth International Kimberlite Conference, Frankfurt am Main, Germany, August 2008, $3 \mathrm{pp}$.

Kurszlaukis, S. and Lorenz, V., 1997. Volcanological features of a low-viscosity melt: the carbonatitic Gross Brukkaros Volcanic Field, Namibia. Bulletin of Volcanology, 58: 421-431.

Kurszlaukis, S. and Lorenz, V., 2008. Formation of "Tuffisitic Kimberlites" by phreatomagmatic processes. Journal of Volcanology and Geothermal Research, 147: 68-80.

Kurszlaukis, S., Mahotkin, I., Rotman, A.Y., Kolesnikov, G.V. and Makovchuk, I.V., 2008. Syn- and post-eruptive volcanic processes in the Yubileinaya kimberlite pipe, Yakutia. Extended abstract, Ninth International Kimberlite Conference, Frankfurt am Main, Germany, August 2008, 3 pp.

Leckie, D.A., Kjarsgaard, B.A., Bloch, J., McIntyre, D., McNeil, D., Stasiuk, L., Heaman, L., 1997. Emplacement and reworking of Cretaceous, diamond-bearing, crater facies kimberlite of central Saskatchewan, Canada. Geological Society of America Bulletin, 109: 1000-1020.

Lefebvre, N. and Kurszlaukis, S., 2008. Contrasting eruption styles of the 147 Kimberlite, Fort à la Corne, Saskatchewan, Canada. Journal of Volcanology and Geothermal Research, 147: 171-185.

Lorenz, V., 1975. Formation of phreatomagmatic maardiatreme volcanoes and its relevance to kimberlite diatremes. Physics and Chemistry of the Earth, 9: 17-27

Lorenz, V., 1979. Phreatomagmatic origin of the olivine melilitite diatremes of the Swabian Alb, Germany. In: F.R. Boyd and H.O.A. Meyer (Eds), Kimberlites, Diatremes and Diamonds: their Geology, Petrology and Geochemistry. American Geophysical Union, Washington, pp. 354-363.

Lorenz, V., 1986. On the growth of maars and diatremes and its relevance to the formation of tuff rings. Bulletin of Volcanology, 48: 265-274.

Lorenz, V., 2003. Maar-diatreme volcanoes, their formation, and their setting in hard-rock and soft-rock environments. Geolines, 15: 72-83. 
Lorenz, V. and Kurszlaukis, S., 1997. On the last explosions of carbonatite pipe G3b, Gross Brukkaros, Namibia. Bulletin of Volcanology, 59: 1-9.

Lorenz V., and Zimanowski, B., 2000. Volcanology of the West Eifel Maars. In: F.O. Neuffer and H. Lutz (Eds) Field trip guidebook, International Maar Conference, Daun/Vulkaneifel, August 17-27 2000, Naturhistorisches Museum Mainz, pp. 5-30.

Lorenz, V. and Kurszlaukis, S., 2007. Root zone processes in the phreatomagmatic pipe emplacement model and consequences for the evolution of maar-diatreme volcanoes. Journal of Volcanology and Geothermal Research, 159: 4-32.

Lorenz, V. and Zimanowski, B., 2008. Volcanology of the West Eifel maars and its relevance to the understanding of kimberlite pipes. Fieldtrip guidebook, Ninth International Kimberlite Conference, Frankfurt am Main, Germany, August 2008, 84 pp.

McClintock M,K, and White, J.D.L., 2000. Phreatomagmatism at Coombs Hills, Antarctica: large-scale laterally quarrying eruptions as a precursor to flood basalt volcanism. Terra Nostra, 6: 336-341

McClintock, M.K. and White, J.D.L., 2006. Large-volume phreatomagmatic vent complex at Coombs Hills, Antarctica records wet, explosive initiation of flood basalt volcanism in the Ferrar LIP. Bulletin of Volcanology, 68: 215-239.

McClintock, M., Marsh, J.S. and White, J.D.L., 2008a. Compositionally diverse magmas erupted close together in space and time within a Karoo flood basalt crater complex. Bulletin of Volcanology, 70: 923-946.

McClintock, M., White, J.D.L., Houghton, B.F. and Skilling, I.P., 2008b. Physical volcanology of a large cratercomplex formed during the initial stages of Karoo flood basalt volcanism, Sterkspruit, Eastern Cape, South Africa. Journal of Volcanology and Geothermal Research, 172: 93-111.

Mitchell, R.H., 1986. Kimberlites: mineralogy, geochemistry and petrology. Plenum Press, New York, 442 pp.

Mitchell, R.H., 1997. Kimberlites, orangeites, lamproites, melilitites, and minettes: a petrographic atlas. Almaz Press Inc, Thunder Bay, Ontario, 243 pp.

Mitchell, R.H., 2008. Petrology of hypabyssal kimberlites: relevance to primary magma compositions. Journal of Volcanology and Geothermal Research, 174: 1-8.

Nemeth, K., White, J.D.L., Reay, A. and Martin, U., 2003. Compositional variation during monogenetic volcano growth and its implications for magma supply to continental volcanic fields. Journal of the Geological Society, 160: 523-530.

Parfitt E.A., 2004. A discussion of the mechanisms of explosive basaltic eruptions. Journal of Volcanology and Geothermal Research, 134: 77-107.

Porritt, L.A., Cas, R.A.F. and Crawford, B.B., 2008. In-vent column collapse as an alternative model for massive volcaniclastic kimberlite emplacement: an example from the Fox kimberlite, Ekati Diamond Mine, NWT, Canada. Journal of Volcanology and Geothermal Research, 174: 90-102.

Reid, A.M., Donaldson, C.H., Dawson, J.B., Brown, R.W. and Ridley, W.I., 1975. The Igwisi Hills extrusive "kimberlites". Physics and Chemistry of the Earth 9, pp. 199-218.

Ross, P.-S., 2005. Volcanology of the Mawson Formation at Coombs and Allan Hills, South Victoria Land, Antarctica. $\mathrm{PhD}$ Thesis, University of Otago, Dunedin, $400 \mathrm{pp}$.

Ross, P.-S. and White, J.D.L., 2005. Mafic, large-volume, pyroclastic density current deposits from phreatomagmatic eruptions in the Ferrar large igneous province, Antarctica. Journal of Geology, 113: 627-649.
Ross, P.-S. and White, J.D.L., 2006. Debris jets in continental phreatomagmatic volcanoes: a field study of their subterranean deposits in the Coombs Hills vent complex, Antarctica. Journal of Volcanology and Geothermal Research, 149: 62-84.

Ross, P.-S., McClintock, M.K. and White, J.D.L., 2008 a. Geological evolution of the Coombs-Allan Hills area, Ferrar large igneous province, Antarctica: debris avalanches, mafic pyroclastic density currents, phreatocauldrons. Journal of Volcanology and Geothermal Research, 172: 38-60.

Ross, P.-S., White, J.D.L., Zimanowski, B. and Büttner, R., 2008b. Rapid injection of particles and gas into nonfluidized granular material, and some volcanological implications. Bulletin of Volcanology, DOI:10.1007/s00445-008-0230-1.

Ross, P.-S., White, J.D.L., Zimanowski, B. and Büttner, R., 2008c. Multiphase flow above explosion sites in debrisfilled volcanic vents: insights from analogue experiments. Journal of Volcanology and Geothermal Research, DOI 10.1016/j.jvolgeores.2008.01.013.

Scott Smith, B.H., 2008. Canadian kimberlites: geological characteristics relevant to emplacement. Journal of Volcanology and Geothermal Research, 174: 9-19.

Sohn, Y.K. and Park, K.H., 2005. Composite tuff ring/cone complexes in Jeju Island, Korea: possible consequences of substrate collapse and vent migration. Journal of Volcanology and Geothermal Research, 141: 157-175.

Sparks, R.S.J., Baker, L., Brown, R.J., Field, M., Schumacher, J., Stripp, G., Walters, A., 2006. Dynamical constraints on kimberlite volcanism. Journal of Volcanology and Geothermal Research, 155: 18-48.

Stasiuk, L.D., Lockhart, G.D., Nassichuk, W.W. and Carlson, J.A., 1999. Thermal maturity evaluation of dispersed organic matter inclusions from kimberlite pipes, Lac de Gras, Northwest Territories, Canada. International Journal of Coal Geology, 40: 1-25.

Sumner, J.M., 1998. Formation of clastogenic lava flows during fissure eruption and scoria cone collapse: the 1986 eruption of Izu-Oshima Volcano, eastern Japan. Bulletin of Volcanology, 60: 195-212.

Sumner, J.M., Blake, S., Matela, R.J. and Wolff, J.A., 2005. Spatter. Journal of Volcanology and Geothermal Research, 142: 49-65.

Tait, M.A. and Brown, R.J., 2008. Explosive Fissure Eruption of a Large Kimberlite Pipe: Venetia K01 Kimberlite Pipe, Limpopo, RSA. Extended abstract, Ninth International Kimberlite Conference, Frankfurt am Main, Germany, August 2008, pp. 1-3.

Tait, M.A., Brown, R.J. and Mnyama, A., 2006. Internal architecture of the Venetia K1 kimberlite: a new geological model and implications for kimberlite emplacement processes, Venetia Mine, Limpopo RSA. 2006 Kimberlite Emplacement Workshop, Saskatoon, Canada, 5 pp.

Thordarson, T., Self, S., Miller, D.J., Larsen, G., and Vilmundardóttir, E.G., 2003. Sulphur release from flood lava eruptions in the Veidivötn, Grímsvötn and Katla volcanic systems, Iceland. In: C. Oppenheimer, D.M. Pyle, and J. Barclay (Eds) Volcanic Degassing. Geological Society of London Special Publication 213, pp. 103-121.

Valentine, G.A. and Groves, K.R., 1996. Entrainment of country rock during basaltic eruptions of the Lucero volcanic field, New Mexico. Journal of Geology, 104: 7190.

van Straaten, B.I., Kopylova, M.G., Russell, J.K., Webb, K.J. and Scott Smith, B.H., 2008. Explosive fragmentation and eruption of kimberlite, insights from the Victor pipe (Canada). Extended abstract, Ninth International 
Kimberlite Conference, Frankfurt am Main, Germany, August 2008, 3 pp.

Walters, A.L., Phillips, J.C., Brown, R.J., Field, M., Gernon, T., Stripp, G., Sparks, R.S.J., 2006. The role of fluidisation in the formation of volcaniclastic kimberlite: grain size observations and experimental investigation. Journal of Volcanology and Geothermal Research, 155: 119-137.

Wilson, L. and Head, J.W., 2007. An integrated model of kimberlite ascent and eruption. Nature, 447: 53-57.

White, J.D.L., 1991. Maar-diatreme phreatomagmatism at Hopi Buttes, Navajo Nation (Arizona), USA. Bulletin of Volcanology, 53: 239-258.

White, J.D.L., 1996. Impure coolants and interaction dynamics of phreatomagmatic eruptions. Journal of Volcanology and Geothermal Research, 74: 155-170.

White, J.D.L. and Houghton, B., 2000. Surtseyan and related phreatomagmatic eruptions. In: H. Sigurdsson, B.
Houghton, S.R. McNutt, H. Rymer and J. Stix (Eds), Encyclopedia of Volcanoes. Academic Press, London, pp. 495-511.

White, J.D.L. and McClintock, M.K., 2001. Immense vent complex marks flood-basalt eruption in a wet, failed rift: Coombs Hills, Antarctica. Geology [Boulder], 29: 935938.

Woolsey, T.S., McCallum, M.E. and Schumm, S.A., 1975. Modeling of diatreme emplacement by fluidization. In: L.H. Ahrens, J.B. Dawson, A.R. Duncan and A.J. Erlank (Eds), Physics and Chemistry of the Earth 9, Pergamon, pp. 11-24.

Zonneveld, J.-P., Kjarsgaard, B.A., Harvey, S.E., Heaman, L.M., McNeil, D.H., Marcia, K.Y., 2004. Sedimentologic and stratigraphic constraints on emplacement of the Star Kimberlite, east-central Saskatchewan. Lithos, 76: 115138.

\section{Figures}

1. Illustrations of features typical of maar-diatreme volcanoes. (a) A dry Holocene maar: Ubehebe Crater, California (700 to 800 m-wide, 235 m-deep; Crowe and Fisher, 1973). The dark gray material is the phreatomagmatic tephra, and the crater cuts deeply into the pre-existing sandstones and conglomerates. (b) A water-filled Quaternary crater: the Weinfeld maar in the West Eifel volcanic field, Germany (700 m diameter, $90 \mathrm{~m}$ deep; Lorenz and Zimanowski, 2008). (c) A quarry wall in the tephra rim of the Quaternary Pulvermaar (West Eifel), showing the extreme abundance of country rock fragments in these surge deposits. Juvenile clasts ( $20 \%$ by volume $)$ are too small to be seen clearly at this scale. (d) The lower part of diatremes is typically occupied by non-bedded, poorly sorted volcaniclastic deposits such as these lapilli-tuffs in the Jurassic Coombs Hills complex (Ross, 2005). A narrow dike of basaltic andesite with a zig-zag pattern cuts the vent fill. (e)-(f) Two photos from Coombs Hills showing that syn-eruptive pyroclastic deposits originally deposited on the ground surface can end-up as (e) rafts or (f) large remnants of a volcanic edifice slumped within diatremes. The raft has steeply dipping lapilli-tuff and tuff beds and is surrounded by heterolithic, non-bedded vent fill. The well-layered tephra ring remnant forms a quarter-circle shape in map view; the sub-vertical exposure (f) shows a dike of juvenile-rich tuff-breccia invading the tephra ring beds.

2. More features of maar-diatreme volcanoes. (a) In the West Eifel, about two thirds of the $\sim 200$ scoria cones had an "initial maar" phase (Lorenz and Zimanowski, 2008). This example, from the Quaternary Hasenberg scoria cone, shows the abrupt transition from phreatomagmatic layers (left of dashed line) to black scoria beds. The schematic section from Lorenz and Zimanowski (2008) shows the approximate location of the photo. (b)-(d) Photos from Coombs Hills and nearby Allan Hills (Ross and White, 2005) illustrate clasts that record multiple cycles of fragmentation and transport: (b) a cored bomb consisting of brown sandstone core with a formerly glassy juvenile rim; (c) a fragment of lapilli-tuff rich in country rock clasts; and (e) a block of fragmented peperite. (e)-(f) Diatremes can contain columnar bodies of volcaniclastic material with differing properties. In map view, these bodies have elliptical to irregular shapes. The Coombs Hills photo (e) shows part of a country rock-rich lapilli-tuff zone cross-cutting the heterolithic vent fill (notebook $\sim 20 \mathrm{~cm}$ long). The plot (f) displays the anisometry and shape factors for columnar bodies at Coombs Hills, based on field mapping with surveying instruments and image analysis (data from Ross, 2005). Anisometry is the ratio of the axes of the best-fitting ellipse: small values represent elongate objects. The shape factor is the perimeter of a circle having the same area as the studied object, divided by the object's perimeter. For a certain anisometry value, the larger the difference in shape factor between the theoretical ellipse curve and the actual data point is, the more irregular the feature (e.g., arrow).

3. Most diatremes contain juvenile particles that have variable vesicularities in single depositional units. These vesicularities tend to be low on average, as illustrated by a photomicrograph of the dominant non-bedded heterolithic lapilli-tuff at Coombs Hills. Juvenile fragments (J) are accompanied by quartz xenocryts (Q) and siltstone fragments (S) in a cement of calcite and zeolites (University of Otago catalogue number OU73150). The graph shows the pointcounted vesicularities (130 to 350 points per fragment) of thirty juvenile clasts larger than $0.5 \mathrm{~mm}$ in average dimension from OU73150 (data from Ross, 2005). 

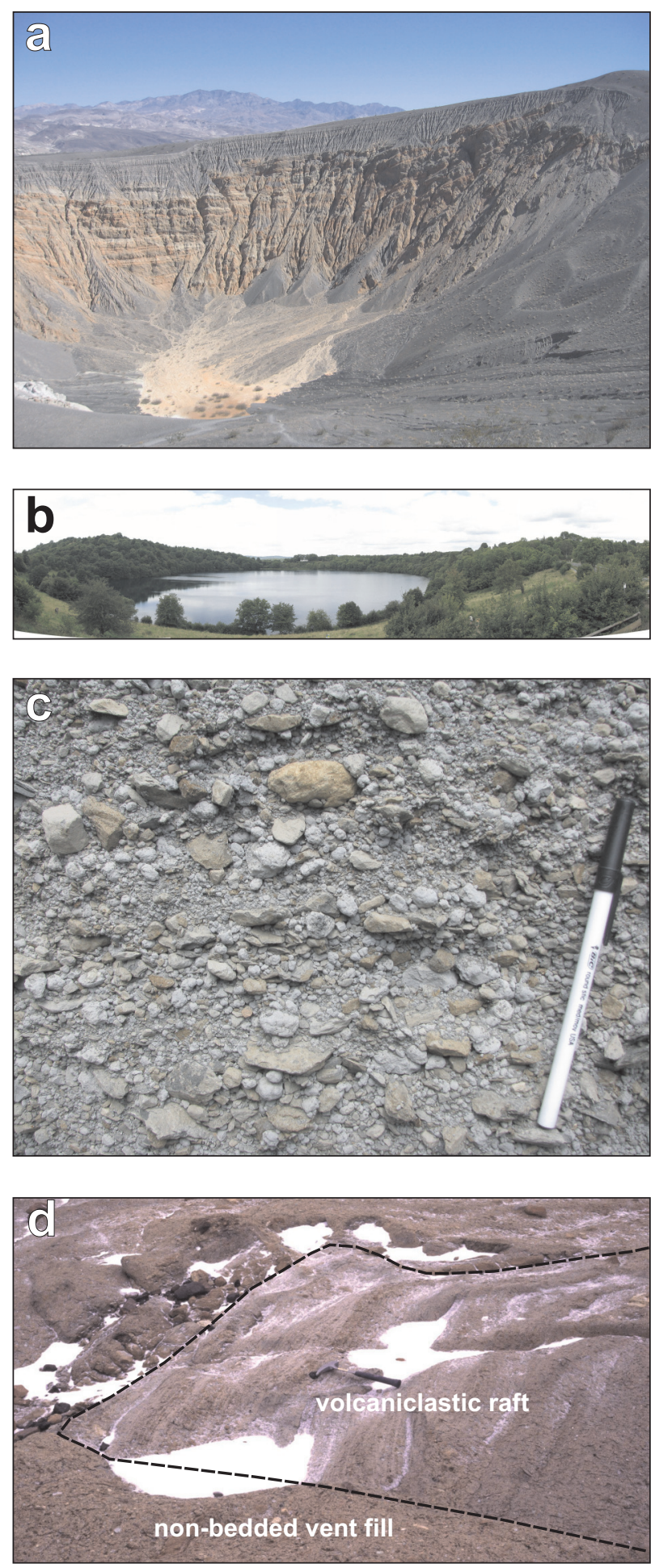

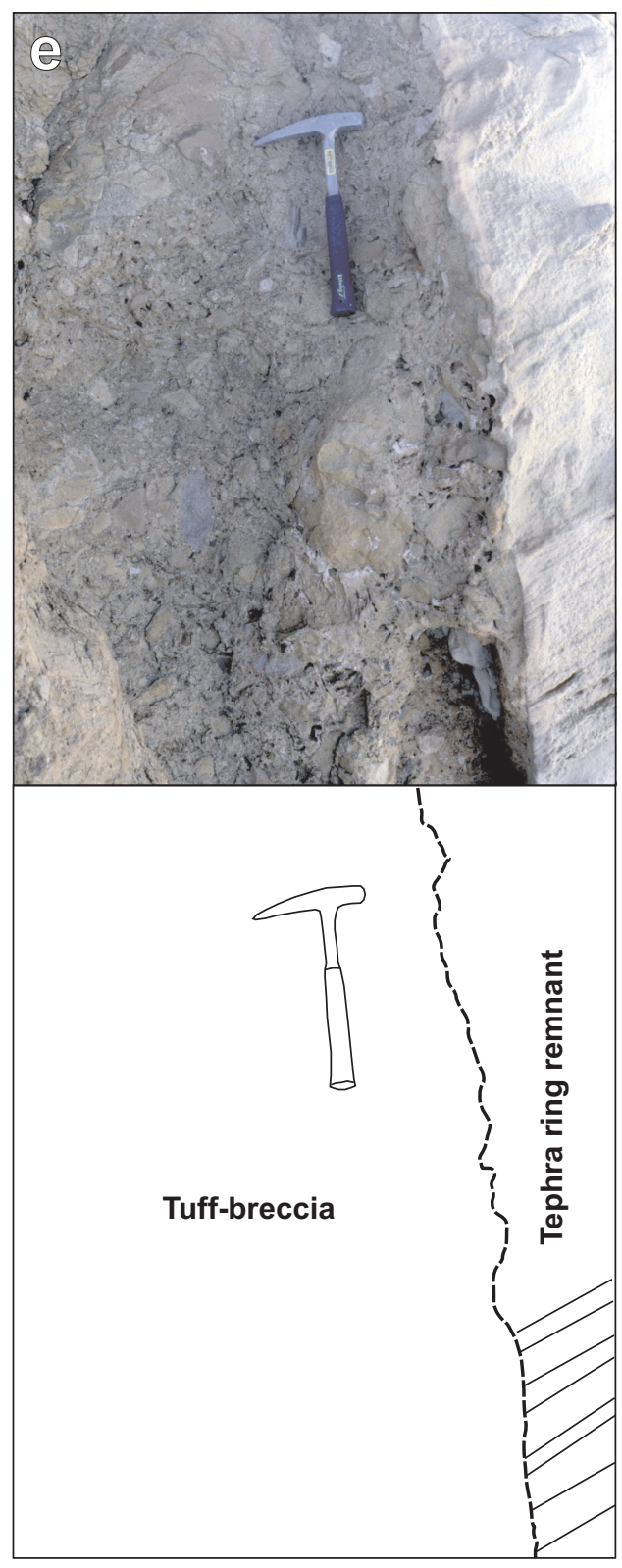

McClintock et al., Fig. 1 

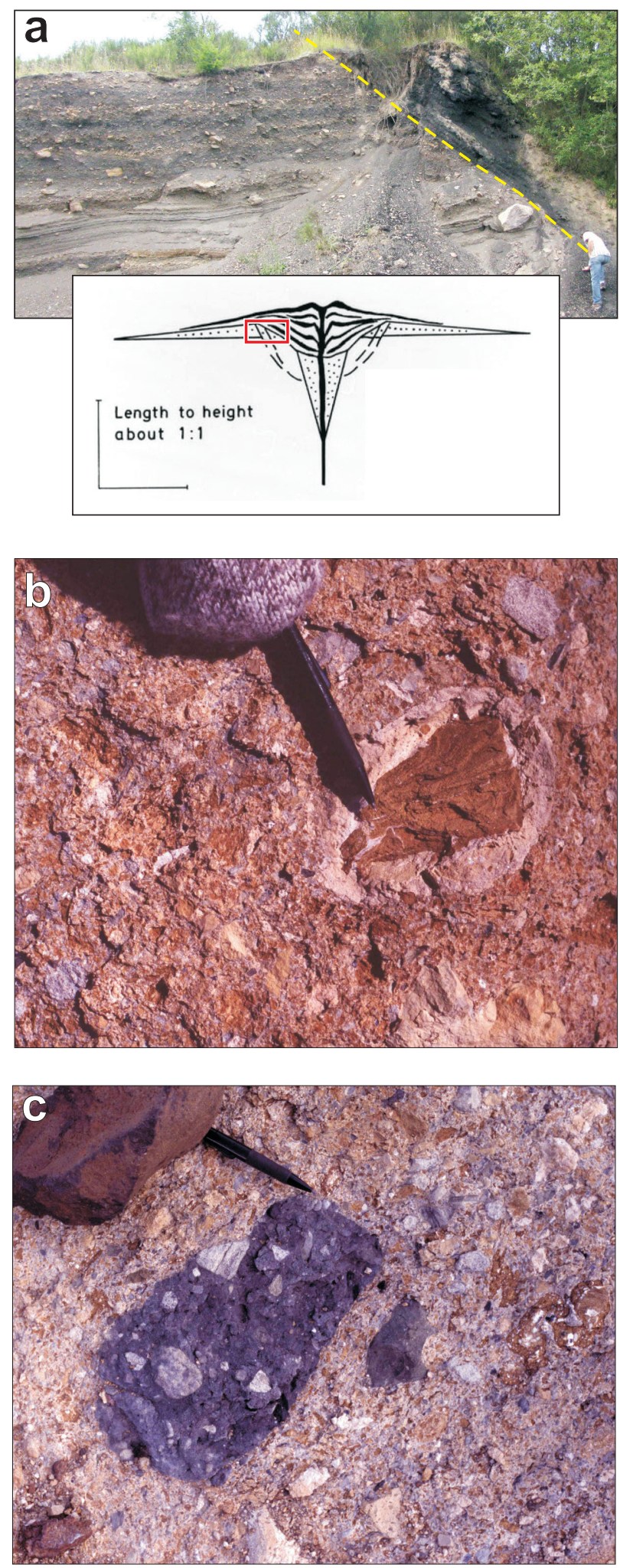
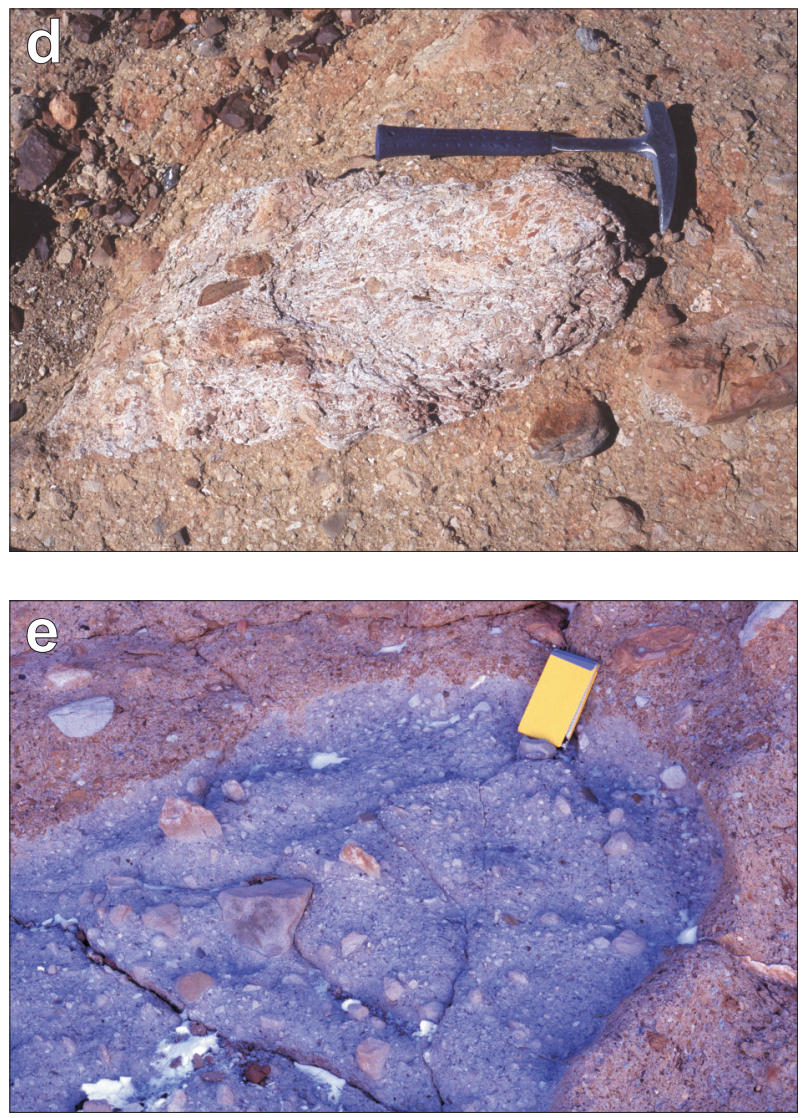

\section{f}

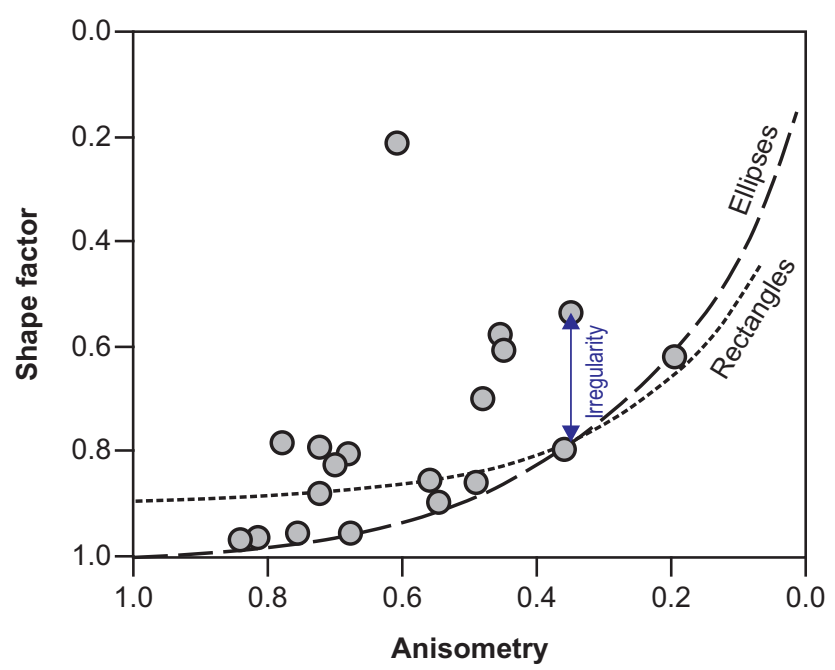



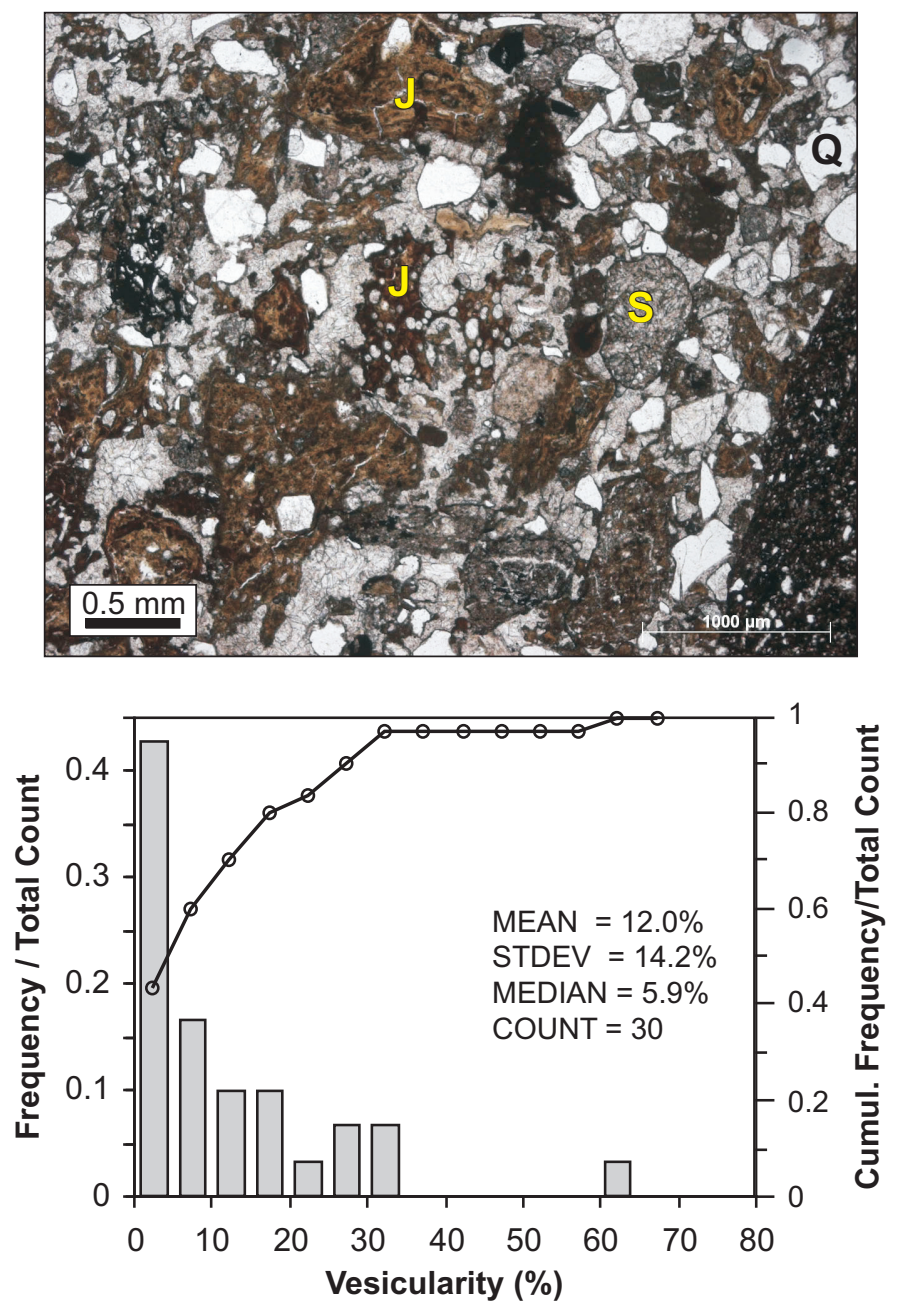

McClintock et al., Fig. 3 